\title{
The Effect of Various Levels of Salt Stress, on Seed Germination of Blue Panicum and the Possibility of Alleviating Damage by Lyso-phosphatidylethanolamine (LPE)
}

\author{
${ }^{*}$ Hanaa M. Abouzied ${ }^{1}$ and K.M. Farag ${ }^{2}$
}

${ }^{1}$ Crop Science Department, Faculty of Agriculture, Damanhour University, Egypt

${ }^{2}$ Horticulture Department, Faculty of Agriculture, Damanhour University, Egypt

*Email: hmmahdy@yahoo.com

Received on: 24/6/2018

Accepted for publication on: 10/7/2018

\section{Abstract}

Panicum antidotale Retz (Blue Panicum) is considered as a new forage crop recently introduced to Egypt, which emphasizes the need for an assessment of its tolerance to salinity stresses. The objectives of the study were to (1) investigate the effect of various levels of salt stress on seed germination, (2) define the threshold of damage by increasing concentration of salt stress, (3) determine the possibility of enhancing seed germination by pretreatment of seeds with lisophos and (4) examine the possibility of synergism between lisophos and low salinity level as to alleviate salt to germinate at certain a concentration of lisophos. Results showed that at a certain extent, there was a synergistic effect between salt concentrations and the percentage of seed germination. Since the soil content with $\mathrm{NaCl}$ of 1000 or $3000 \mathrm{ppm}$ led to a significant increase in the germination (61.75\% and 53.95\% respectively) as compared with the control (47.70\%). The influence of various used concentrations $(0 \mathrm{ppm}, 5 \mathrm{ppm}, 10 \mathrm{ppm}, 20 \mathrm{ppm}$ and 40 ppm) of the natural compound lisophos on germination percentage of the pretreating seeds revealed that the control seeds had the least germination percentage among all treatments. To check the possibility of alleviating salinity stress injury, lisophos used concentrations at $5 \mathrm{ppm}$ and $20 \mathrm{ppm}$, were used to protect the seed then seeds were exposed to salinity stress concentrations. Data showed that there was a significant increase in the germination percentage of Blue Panicum by the application of lisophos at $5 \mathrm{ppm}$ to salt exposed seeds at $5000 \mathrm{ppm}$. On other hand data indicated that there was an adverse effect on the germination percentage by applying lisophos at $20 \mathrm{ppm}$ in the presence of salinity at 3000 ppm or $5000 \mathrm{ppm}$ since the highest percentage was obtained with the control. This study may add valuable information about Panicum antidotale tolerance to salinity as well as capability and potentialty of lithophosphatidyl ethanol amine (lisophosph or LPE) as growth regulators in stimulating germination of Panicum antidotale seeds and alleviating the damage of salinity to the ability of seeds to germinate.

Keywords: Lyso-phosphatidylethanolamine (LPE), Panicum antidotale, salinity, germination.

\section{Introduction}

Panicum antidotale Retz plant has two common names Blue Panicumor Blue Panic. The name Blue came from, the green leaves tend to be blue in color (Freckmann, 2011; Quattrocchi, 2006). This plant is a perennial grassit has been recently introduced to Egypt as forage grass crop. This grass has many fea- 
tures attracted several farmers as it is known of its several branches and deep root originated from shallow bulbous rhizomes roots (FAO, 2011; Humphreys and Partridge, 1995; Heuzé et al., 2016), has stems of up to 2.5 meters. Panicum antidotale is now cultivated in many countries (FAO, 2011) but is considered a weed in California (USDA, 2011). Blue Panicum based on the seasons, soil fertility, water availability can produce from 10-50 tons of fresh material/ha (Eco crop, 2011; Heuzé et al, 2016). In addition, Blue Panicum contains high protein content that reach 10 to $11 \%$, while it recover rapidly after grazing (Muhammad,1989). Panicum antidotale can be cultivated solitary or combined with some grasses like Cenchrusciliaris in pastures. Farmers can drill seed in rows $(45-100 \mathrm{~cm}$ apart) or broadcast (Heuzé et al, 2016). Panicum antidotale started its vegetative growth with slow speed and then speed up after the first 6 and 8 weeks of germination. To keep the nutritive value and sustain grass vigor as long as possible for this plant it is important to frequently and heavily graze Blue Panicum to avoid plant to mature and enter the woody stage (FAO, 2011; Heuzé et al., 2016).

At this moment many studies concerning species are extremely needed to provide farmers and producers across Egypt with sufficient and detailed information about its cultivation, seed germination, production, impact on the environment, and its feeding value for the farm animals. Species in general have the capability to grow in different conditions, soil and environments, and the best growth is in well-drained soil with reasonable fertility like sandy clay soil or light clay and the pant prefers to grow under high temperature and sunny climate [Huxley 1992].

Salt tolerance is another important and attractive characteristic of Panicum antidotale and added another economic value to its use in cultivation (Al-Solaimani et al., 2009; Khan et al., 2009; Ahmad et al., 2010). Some genotypes from Blue Panicum have been cultivated on soil of high salinity levels (Heuzé et al., 2016). Based on seed and forage yields, Panicum antidotale seemed to be more tolerant to high levels of salinity than other pastures, like Dichantium annulatum and Cenchrus ciliaris (Qadir et al, 2008).

Egypt has an arid climate and suffers from salinization problems in Nile Delta valley due to the intensive irrigation and scarcely of rainfall (Tarek et al., 2000). In Egypt about $35 \%$ of the cultivated lands undergo salinity, and the E.C of the extract from saturated soil was found to be above $4 \mathrm{dS} / \mathrm{m}$ (GARE, 1992; Tarek et al., 2000).

Percentage of germinated seed can be significantly dropped when high salinity occurred in soil (Jalali et al., 2010). To enhance the capability of seed to germinate under adverse condition many seed treatments have been adopted to stimulate seed germination such as gibberellic acid, ABA, KNO3, NaNO3, nitric oxides, ethanol as well as smoke and ionizing radiation especially in warm seasongrasses (Ogawa et al., 2003; O1szewski et al., 2002, Nambara and Marion-Poll, 2005). On the other hand, lithophosphatidyl ethanol 
amine is alysophosph lipid that has reported to stimulate seed germination and to enhance the vigor of the resulting seedling whether through seed priming or direct seeding following the treatment (Farag et al., 2003). It was found also that this natural compound alleviate the injury resulting from rapid seed imbibition which protect the seed cell membrane against damage. This compound (produced under trade or commercial name called Liso) increases the plant tolerance to the environmental stresses and mitigate the adverse effect of some biotic and abiotic stresses (Farag et al., 2003; Cowan et al., 2006) at low concentrations.

Seedling is the most vulnerable stage in life cycle of plant and germination determined when seedling growth begins (Harper, 1977). In order to add some information about Blue Panicum germination a simple protocol was used by Wuest (2007) for germination procedures was used to obtain accurate and reproducible incubation condition.

Characterizing Blue Panicum as a new forage crop and detection its tolerance to salinity stress and other biotic and abiotic stresses is essential for providing information about its production and also for plant breeding programs. However, no research has been testified the salinity tolerance of Blue Panicum. Thus, the objectives of the study were to: (1) investigate the effect of various levels of salt stress, on seed germination. (2) define the threshold of damage by increasing concentration of salt stress (3) determine the possibility of enhancing seed germination by pretreatment of seeds with lisophos (4) examine the possibility of synergism between lisophos and low salinity level as to alleviate salt damage to germination at certain concentration of lisophos.

\section{Materials and Methods Plant Materials}

This study was carried out at $\mathrm{s}$ agronomy seed laboratory, crop science department, faculty of Agriculture, Damanhur University, Egypt during the year 2017 at September, October, November and December for the first, second, third and fourth experiment respectively. The aims were to study the germination of the new introduced forage plant Panicum antidotale Retunder normal, salinity stress and growth regulators condition by using a controlled and reproducible system or protocol. Fresh seed were obtained from Agricultural Research Center (ARC), Egypt.

\section{Seed Planting System}

The protocol of germination used in this study is adopted from (Wuest, 2007; Wuest and Lutcher, 2012) for wheat and modified to suit seeds. The soil solution was based on the water or $\mathrm{NaCl}$ concentrations. The soil mixture used in this study was made from equal proportions of peatmoss, vermiculite and sand. Each of the soil solution treatment and $70 \mathrm{~g}$ of soil were mixed for one to two minutes before being placed into the petri dishes (Figure 1). The amount of soil solution added was adjusted to reach full soil saturation without excess water. Pretreated seeds were soaked in the lisophos treatments for two hours then allowed to air dry at ambient temperature in the laboratory $22 \pm 2^{\circ} \mathrm{C}$. All the four experiments were each done in factorial form 
(treatments $\mathrm{x}$ days of germination) treatment number varies from one experiment to another and time factor are two ( 7 and 14 days), using a completely randomized design with ten replications. One piece of filter paper was set on top of the wet soil and seeds were placed on top of the filter paper in order to see the development and to avoid interference with germination. Sixty seeds were then placed on the filter paper, covered with the lid, and incubated at $22 \pm 2{ }^{\circ} \mathrm{C}$. Light was turned on in the incubator for eight hours per day. The petri dishes were placed lid side down in the incubator in order for the plumules to grow towards the lid and easier to see. Seeds were grown and observed for up to 14 days. However, as normally germinates in three to four days, many of the treatments were fully germinated and scored at 14 days. Germination was scored on the seventh day and fourteenth day after the incubation of the experiment. When a 5-millimeter root or shoot sprouted from the seed, it was considered as germinated. The total number of seeds germinated per petri dish by the end of the experiment was used to measure the germination percentage. This indicated if the rate of germination was affected by the treatments and time. Germination percentage out of 60 seeds was calculated for each petri dish experimental unit. Analysis of variance for germination test was conducted by the PROC GLM procedure of SAS (SAS Inst., Cary, NC, USA). Treatments means were considered significantly different at $\mathrm{P}<0.05$.



Figure 1: Illustration of the system used to test the germination of seeds treated with either water or various concentrations of lisophos then exposed to saline solutions

\section{Protocols}

The first study

Germination test on Nacl concentrations: The experiment was carried out to study the effect of $\mathrm{NaCl}$ concentrations on the germination of Blue Panicum. Seven concentration from $\mathrm{NaCl}$ were used $0,1000,3000$, 5000, 7000, 9000 and 11,000 ppm to treat the soil part while seeds were pretreated in water by soaking for 2 hours.

\section{The second study}

Germination tests of seeds pretreated with different Lisophos concentrations: The Experiment was done to study the effect of the pretreated seeds with lisophos concentrations before planting on the enhancement of the germination of Blue Panicum. Five concentrations ( 0 ppm, 5 ppm, 10 ppm, 20 ppm and 40 ppm) were used from lisophos to pretreat seeds before planting in the petri dish system while the soil compartment was reared with just water.

\section{The third Study}

Germination tests of seed pretreated with 5 ppm lisophos across different concentrations of $\mathrm{NaCl}$ : The experiment three: was conducted to study the effect pretreated seeds with economically concentration of lisophos (5 ppm) on the enhancement of Blue Panicum germination under 
different $\mathrm{NaCl}$ concentrations $(0$, $1000,3000,5000,7000,9000$ and $11,000 \mathrm{ppm})$ in the soil compartment.

\section{The fourth study}

Germination tests of seed pretreated with $20 \mathrm{ppm}$ lisophos across different concentrations of $\mathrm{NaCl}$ : The experiment was conducted to study the effect pretreated seeds with high concentration of lisophos 20 ppm on the enhancement of Blue Panicum germination under different $\mathrm{NaCl}$ concentrations $(0,1000,3000$, $5000,7000,9000$ and $11,000 \mathrm{ppm}$ ) to the soil compartment.

\section{Statistical analysis}

All experiments were done in two way factorial arrangement in CRD with 10 replications. The first factor was the treatments concentrations and the second factor was the number of days after planting in petri dishes. Analysis of variance for germination test was conducted by the PROC GLM procedure of SAS (SAS Inst, Cary, NC, USA). Germination percentages were subjected to arcsin transformation before analysis of variance. The differences between the means were compared by the least significant difference (LSD) test $(\mathrm{p} \leq 0.05)$. Treatments means were considered significantly different at $\mathrm{P}<0.05$.

\section{Results and Discussion \\ 1- Germination test on $\mathrm{NaCl}$ con- centrations}

To further define the threshold of damage by salt stress for the germination of Blue Panicum seeds, an experimental study was carried out using wide scale of salts concentrations $(0,1000,3000,5000,7000$, 9000 and $11,000 \mathrm{ppm}$ ) in the soil solution. The data presented in Table
(1) showed that at a certain extent, there was a synergistic effect between salt concentrations and the percentage of seed germination. Since the soil content with $\mathrm{NaCl}$ of 1000 or 3000 ppm (led to a significant increase in the germination $(61.75 \%$ and $53.95 \%$ respectively) as compared with the control $(47.70 \%)$. When salinity was further increased to 5000, 7000, $9000 \mathrm{ppm}$ or $11000 \mathrm{ppm}$, there were a parallel reduction in Blue Panicum seed germination $(43.85,32.20,19.30$ and $11.45 \%$ respectively). In other word, the least germination percentage was obtained with $\mathrm{NaCl}$ in the soil solution at $110000 \mathrm{ppm}$ followed by $\mathrm{NaCl}$ at $9000 \mathrm{ppm}$ that also resulted in a significant reduction in germination percentage relative to the control or even relative to salinity at $1000 \mathrm{ppm}$ or $3000 \mathrm{ppm}$. Moreover, the time factor revealed that there was a significant increase in the germination of Blue Panicum seeds over the incubation period from 7 to 14 days (19.42 and 58.33 respectively) at the ambient temperature regardless the used treatment. The interaction between the used treatment and the time factor (Table 2) revealed that the greatest increase after 14 days of treatment occurred with seeds on soil solution with 1000 or $3000 \mathrm{ppm}$ from $\mathrm{NaCl}$ which both gave $(82.0 \%)$. However, there was a significant increase in seed germination between 7 and 14 days of treatment with varying magnitude of increase. The greatest adverse effect on the germination percentage of Blue Panicum seeds was found with $\mathrm{NaCL}$ at $11000 \mathrm{ppm}$ followed by salinity at $9000 \mathrm{ppm}$ then at $70000 \mathrm{ppm}$. Thus the magnitude of reduction in the germination of Blue 
Panicum seed germination was proportion to the increase of $\mathrm{NaCl}$ concentration with the threshold of damage to germination starting at 5000 ppm.

Field and greenhouse studies on Blue Pancium tolerance to salinity are limited at this moment. In general spp. are expected to be a very good source for feeding animal for their high nutrition value (Khan et al., 2009) and recognized to be the most promising species under saline conditions in sandy loam soil (Tomar et al., 2003). One study conducted by (AlDakheel et al., 2015b) showed that Panicummaximiun is stand well in soil affected with salinity and considered as moderate species for salt tolerance. Salinity stress for any crop can interfere its physiological process by different manner (Negrão et al., 2017) this disruption started with reduction in plant germination percentage or delay it or even completely stop germination, these can led to incomplete density of pant in the field, some stunted and abnormal growth may appear and finally poor yield obtained (Ahmad et al., 2010; Ihsan et al., 2018). Liu et al., (2014) found that salinityhad synergetic effects on the germination percentage of Pnicumvirgatum.

Table 1. Analysis of variance for germination at 7 days and germination at 14 days of the Blue Panicum with different experimental treatments.

\begin{tabular}{|l|c|c|c|c|}
\hline \multirow{2}{*}{\multicolumn{1}{|c|}{ Source of variations }} & \multicolumn{2}{|c|}{ First study } & \multicolumn{2}{c|}{ Second study } \\
\cline { 2 - 5 } & d.f. $^{\text {a }}$ & Mean square & d.f. $^{\text {a }}$ & Mean square \\
\hline Treatments & 6 & $3019.13^{* *}$ & 4 & $5166.20^{* *}$ \\
\hline Days & 1 & $21850.93^{* *}$ & 1 & $6067.16^{* *}$ \\
\hline Treatments *Days & 6 & $400.68^{* *}$ & 4 & $332.66^{* *}$ \\
\hline Error & 126 & 28.01 & 90 & 82.55 \\
\hline & \multicolumn{2}{|c|}{ Third Study } & \multicolumn{2}{|c|}{ Fourth Study } \\
\hline Source of variations & d.f. $^{\text {a }}$ & Mean square & d.f. $^{\text {a }}$ & Mean square \\
\hline Treatments & 6 & $320.53^{* *}$ & 3 & $2181.34^{* *}$ \\
\hline Days & 1 & $11490.28^{* *}$ & 1 & $951.23^{*}$ \\
\hline Treatments *Days & 6 & $123.62^{* *}$ & 3 & $65.19 \mathrm{~ns}$ \\
\hline Error & 126 & 24.03 & 72 & 94.61 \\
\hline
\end{tabular}

${ }^{\mathrm{a}}$ : degree of freedom, ns: non-significant, ${ }^{*}$ Significant at $\mathrm{p}$-value $=0.05$ and ${ }^{* *}$ Significant at $\mathrm{p}$ value $=0.01$

Table 2. First Study: Mean percent age of germination test on NaCl treatments, and days after planting.

\begin{tabular}{|l|c|c|c|}
\hline \multicolumn{1}{|c|}{$\begin{array}{c}\text { NaCl conc. } \\
\text { In ppm }\end{array}$} & 7 Days after planting & 14 Days after planting & Mean \\
\hline $\mathbf{0}$ & $19.60 \mathrm{fg}$ & $75.80 \mathrm{a}$ & $47.70 \mathrm{C}$ \\
\hline $\mathbf{1 0 0 0}$ & $41.50 \mathrm{~d}$ & $82.00 \mathrm{a}$ & $61.75 \mathrm{~A}$ \\
\hline $\mathbf{3 0 0 0}$ & $25.90 \mathrm{ef}$ & $82.00 \mathrm{a}$ & $53.95 \mathrm{~B}$ \\
\hline $\mathbf{5 0 0 0}$ & $22.50 \mathrm{efg}$ & $65.20 \mathrm{~b}$ & $43.85 \mathrm{C}$ \\
\hline $\mathbf{7 0 0 0}$ & $10.80 \mathrm{ij}$ & $53.60 \mathrm{c}$ & $32.20 \mathrm{D}$ \\
\hline $\mathbf{9 0 0 0}$ & $12.09 \mathrm{hi}$ & $28.11 \mathrm{e}$ & $19.30 \mathrm{E}$ \\
\hline $\mathbf{1 1 0 0 0}$ & $4.30 \mathrm{j}$ & $18.60 \mathrm{gh}$ & $11.45 \mathrm{~F}$ \\
\hline Mean & $19.42 \mathrm{~B}$ & $58.33 \mathrm{~A}$ & \\
\hline
\end{tabular}

Data in the same column with different letters indicate a significant difference at $\mathrm{P}<0.05$ 
2-Germination tests of seed pretreated with different lisophos concentrations

The influence of various used concentration $(0 \mathrm{ppm}, 5 \mathrm{ppm}, 10$ ppm, $20 \mathrm{ppm}$ and $40 \mathrm{ppm})$ of the natural compound lisophos on germination percentage of the pretreating seeds before planting in the petri dish was reported in (Table 3, Figure 2). The data revealed that the control seeds had the least germination percentage among all treatments. Meanwhile, seeds soaked in lisophos at 5 ppm had a significant increase in their germination as compared with the control. Moreover the response of the seeds to the used concentration gradient showed no further significant alteration in the percentage of germination between pretreatment with lisophos at $5.0 \mathrm{ppm}$ or at 40 ppm. Thus, it is more economic to use $5.0 \mathrm{ppm}$ especially on the production at a large scale. The data also indicated that the concentration of lisophos was increased from 10 to 20 ppm, there was an increase in the germination percentage while the increase from $20 \mathrm{ppm}$ to $40 \mathrm{ppm}$, there was a significant reduction in such percentage. The time factor indicated to significant change in the germination between the seventh day after treatment compared with assessment after 14 days. Furthermore, the interaction between applied treatment and the time factor showed that all treated seed had a significant increase in the germination percentage in the second assessment after 14 days except with lisophos treated seeds at $20 \mathrm{ppm}$. The greatest increase over two weeks was obtained with those seed tested with lisophosconcentration were equally effective on increasing the germina- tion after 14 days of the treatment. Insight of the significant increase in the germination percentage in the control seed, but still its percentage after 14 days was lower them other treatments.

Phosphatidylethanolamine is reported as the second most plentiful glycerophospholipid in eukaryotic cells (Calzada et al., 2016) and has a number of miscellaneous applications. Phospholipid such as lisophos is considered as plant growth regulator and maintain cell membrane in its healthierstate (Attia and Farag, 2017). Researchers have found that lysophos phatidylethanolamine (LPE) stops one of the key enzymes that breakdown membrane phospholipids so helping to maintain the membranes of living cell healthy, some of diverse application of LPE is prolonging the shelf life of cutting flowers, enhance fruit and plant quality and hastens ripening. Significant researches in field of seed germination is a provide information of high impact to the economic production of the crop and reduce of many agricultural practices to compensate the problem in seed germination in the field. (Asomaning et al., 2011; Suleman et al., 2011). Germination Seed treatment whether by priming techniques or soaking followed by direct seeding can allow seed to germinate and emerge even under adverse agro-climatic conditions Seed treatments is not only promoted germination percentage but they stimulated earlier and stronger plant establishment, also, overcome thermo and photo abiotic stresses and uniform emergence when planted (lee and Kim, 1999; Basra, 2003). 
Table 3. Second study: Mean percent age of germination on lisophos concentrations, and days after planting.

\begin{tabular}{|l|c|c|c|}
\hline $\begin{array}{c}\text { Lisophos Conc. } \\
(\mathbf{p p m})\end{array}$ & $\mathbf{7}$ Days after planting & 14 Days after planting & Mean \\
\hline $\mathbf{0}$ & $22.70 \mathrm{~d}$ & $34.500 \mathrm{c}$ & $28.6 \mathrm{~d}$ \\
\hline $\mathbf{5}$ & $68.30 \mathrm{~b}$ & $87.80 \mathrm{a}$ & $78.05 \mathrm{~b}$ \\
\hline $\mathbf{1 0}$ & $44.20 \mathrm{c}$ & $86.00 \mathrm{a}$ & $65.1 \mathrm{c}$ \\
\hline $\mathbf{2 0}$ & $83.40 \mathrm{a}$ & $89.66 \mathrm{a}$ & $86.53 \mathrm{a}$ \\
\hline $\mathbf{4 0}$ & $65.30 \mathrm{~b}$ & $92.80 \mathrm{a}$ & $79.05 \mathrm{~b}$ \\
\hline Mean & $56.78 \mathrm{~B}$ & $78.30 \mathrm{~A}$ & \\
\hline
\end{tabular}

Data in the same column with different letters indicate a significant difference at $\mathrm{P}<0.05$



Figure 2. The effect of various concentrations of lisophos on the germination percentage of the pretreated seed of Blue Panicum after 7 days of planting in petri dish system.

3- Germination tests of seed pretreated with 5 ppm lisophos across different concentrations of $\mathrm{NaCl}$

To determine any possibility of synergism between low concentration of lisophos at 5 ppm and salinity levels in the soil solution, this study was conducted by using various concentration of $\mathrm{NaCl}$ that were $1000 \mathrm{ppm}$ $3000 \mathrm{ppm}, 5000 \mathrm{ppm}, 7000 \mathrm{ppm}$, $9000 \mathrm{ppm}$, and $11000 \mathrm{ppm}$. The reported data in (Table 4). Showed that there was a significant increase in the germination percentage of Blue Panicum by the application of lisophos at $5 \mathrm{ppm}$ to salt exposed seeds at 5000 ppm. However, lisophos - treated seeds by the same concentration that were exposed to salinity of 11000 ppm had a significant reduction in their germination as compared with the control or with lisophos at $5 \mathrm{ppm}$ in the presence of $2000 \mathrm{ppm}$ of $\mathrm{NaCl}$. The time factor showed again a significant increase in the germination between the seventh day of incuba- 
tion at ambient temperature at $22^{\circ} \mathrm{C}$ compared with after 14 days assessment at the same conditions.

Meanwhile, the interaction effect between treatments and the time factor revealed that the greatest increase in the percentage of germination over time was obtained with lisophos treated seeds at $5 \mathrm{ppm}$ after 14 days of incubation while exposed to $1000 \mathrm{ppm}$ of salinity. Moreover, seeds exposed to $7000 \mathrm{ppm}, 9000$ ppm or $11000 \mathrm{ppm}$ of salinity had similar percentage of germination whaen compared with control after 14 days of the incubation when pretreated with lisophos at $5 \mathrm{ppm}$. Meanwhile the incubation of lisophos at $5 \mathrm{ppm}$ - treated seeds in the presence of 3000 or $5000 \mathrm{ppm}$ of Nacl was still able to to stimulate the germination of Blue Panicum after 14 days at ambient temperature. Thus lisophos at 5 ppm was able to alleviate the injury of salts to a certain extent which had a synergistic influence on germination when seeds were incubated along with salinity of 1000 $\mathrm{ppm}$. For maximizing the natural potential of crop seed in the field need to test different compound presented naturally like lisophos or any other synthetic compound. This study is aimed to explore the potential of lysophos pholipids in stimulating germination of seed under salinity stress condition. It has been reported that phospholipidis important in all plant stages and growth. Moreover, they has vital role in many physiological process to plant such as embryo maturation, seed germination,stimulated cell division and growth, osmotic adjustment and stress tolerance, and organ senescence (Laxaltand Munnik, 2002; Cowan 2006).

Table 4. Third study: Mean percent age of germination tests of seed pretreated with 5 ppm lisophos across different concentrations of $\mathrm{NaCl}$.

\begin{tabular}{|l|c|c|c|}
\hline $\begin{array}{c}\text { NaCl Conc. } \\
\text { (ppm) }\end{array}$ & 7 Days after planting & 14 Days after planting & Mean \\
\hline $\mathbf{0}$ & $76.30 \mathrm{e}$ & $87.50 \mathrm{~cd}$ & $81.900 \mathrm{~B}$ \\
\hline $\mathbf{1 0 0 0}$ & $68.40 \mathrm{f}$ & $95.90 \mathrm{a}$ & $82.150 \mathrm{~B}$ \\
\hline $\mathbf{3 0 0 0}$ & $60.00 \mathrm{gh}$ & $85.10 \mathrm{~d}$ & $72.550 \mathrm{CD}$ \\
\hline $\mathbf{5 0 0 0}$ & $78.10 \mathrm{e}$ & $93.80 \mathrm{ab}$ & $85.950 \mathrm{~A}$ \\
\hline $\mathbf{7 0 0 0}$ & $61.60 \mathrm{~g}$ & $88.60 \mathrm{bcd}$ & $75.100 \mathrm{CD}$ \\
\hline $\mathbf{9 0 0 0}$ & $63.09 \mathrm{~g}$ & $92.2 \mathrm{abc}$ & $76.200 \mathrm{C}$ \\
\hline $\mathbf{1 1 0 0 0}$ & $56.10 \mathrm{~h}$ & $88.20 \mathrm{~cd}$ & $72.150 \mathrm{D}$ \\
\hline Mean & $66.18 \mathrm{~B}$ & $90.15 \mathrm{~A}$ & \\
\hline
\end{tabular}

Data in the same column with different letters indicate a significant difference at $\mathrm{P}<0.05$

4- Germination tests of seed pretreated with $20 \mathrm{ppm}$ lisophos across different concentrations of $\mathrm{NaCl}$

To check the possibility of alleviating salinity stress injury, lisophos used concentration at $20 \mathrm{ppm}$, as concluded from the second experiment the study was used to protect the seed then they were exposed to salinity stress at either 1000,3000 , or 500 ppm (Table 5). The data indicated that there was an adverse effect on the germination percentage by applying lisophos at $20 \mathrm{pp}$ in the presence of salinity at $3000 \mathrm{ppm}$ or $5000 \mathrm{ppm}$ since the highest percentage was ob- 
tained with the control (water treatment to both the seeds and was obtained with the control (water treatment to both the seeds and the soil system). However the time factor indicated to a significant increase in the germinated seeds after 14 days of incubation as compared with that after 17 days. Regarding the interaction between the treatments and the time factor (Table 4). The data showed a trend of increase in the germination percentage between 7 and 14 days of incubation periods in the control and lisophos treated seed then exposed to adjacent salinity at $5000 \mathrm{ppm}$. However, no difference was found over that period between seeds exposed to either $3000 \mathrm{ppm}$ or $5000 \mathrm{ppm}$ that were pretreated with either 3000 or $5000 \mathrm{ppm}$ that were pretreated with lisophos at $20 \mathrm{ppm}$. Thus the use of lisophos at relatively higher concentration was able to alleviate the damaging effect of $5000 \mathrm{ppm}$ of $\mathrm{Nacl}$ (Table 4). It is now well establish the role of phospholipids in promoting plant development and maintain it healthy also across the agrochemical markets there are many phospholipid- based growth regulators for commercial agriculture application which is open an attractive and challenging field of research(Cowman, 2006). Lisophos may act to repair the damage to seed cells membranes, which avoid its damage (Farag and Palta, 2003). The ability of germination under different concentrations of lisophos could be attributed to the effect of lisophos on enhancing the activity of the natural GA formation and its effect on the increase in $\alpha$-Amytase enzyme that causes the bioassay of starch to sugar (Arfeca, 1996).

The exposure to certain lisophos concentration was also able to mitigate the damage by some abiotic or biotic stresses and maintaining the integrity if the seeds cell plasma membrane (Farag and Palta, 2003). It was also reported that the lysophosphatidylethanlalamine might be delaying tissue senescence and reducing electrolyte leakage through the plasma membrane by repairing the damage of that membrane, thus reducing cell leakage and reducing the injury of rapid imbibition (Farag and Palta, 1993).

Table 5. Fourth Study: Mean percent age of germination tests of seed pretreated with 20 ppm lisophos across different concentrations of $\mathrm{NaCl}$

\begin{tabular}{|l|c|c|c|}
\hline $\begin{array}{c}\text { NaCl Conc. } \\
\text { (ppm) }\end{array}$ & 7 Days after planting & 14 Days after planting & Mean \\
\hline $\mathbf{0}$ & $68.10 \mathrm{a} \mathrm{b}$ & $78.20 \mathrm{a}$ & $73.15 \mathrm{~A}$ \\
\hline $\mathbf{1 0 0 0}$ & $41.30 \mathrm{~b}$ & $51.30 \mathrm{~b}$ & $46.30 \mathrm{~B}$ \\
\hline $\mathbf{3 0 0 0}$ & $46.40 \mathrm{~b}$ & $50.30 \mathrm{~b}$ & $48.35 \mathrm{~B}$ \\
\hline $\mathbf{5 0 0 0}$ & $27.30 \mathrm{c}$ & $43.10 \mathrm{~b}$ & $35.20 \mathrm{C}$ \\
\hline Mean & $45.77 \mathrm{~B}$ & $55.72 \mathrm{~A}$ & \\
\hline
\end{tabular}

Data in the same column with different letters indicate a significant difference at $\mathrm{P}<0.05$

\section{Conclusion}

This investigation is considered as preliminary study to explore the potential of the new crop Blue pan- cuim as salt tolerant crop using suitable protocol for germination able to observe germination clearly in petri dish using real soil than using small 
pots. Results of this study revealed that Blue Panicum. Showed a significant increase in the germination on the soil content with $\mathrm{NaCl}$ of 1000 or $3000 \mathrm{ppm}$. Seed pretreated with 5 ppm lisophos protected the seed from salinity injury on concentration up to $5000 \mathrm{ppm}$. On other hand data indicated that there was an adverse effect on the germination percentage by applying high concentration of lisophos (20 ppm) under salinity condition $3000 \mathrm{ppm}$ or $5000 \mathrm{ppm}$ since the highest percentage was obtained with the control. The study concluded that Blue Pancium is a salt tolerant crop, seed pretreated with plant growth regulators like lisophos may increase its tolerance when apply at certain concentrations or dose.

\section{References}

Ahmad, M. S. A.; A. Muhammad; A. Qasim (2010). Soil salinity as a selection pressure is a key determinant for the evolution of salt tolerance in Blue Panicgrass (antidotale Retz.). Flora (Jena). 205 (1): 37-45.

Ahmad, M.S.A.; M. Ashraf, Q. Ali (2010). Soil salinity as a selection pressure is a key determinant for the evolution of salt tolerance in Blue Panic grass (antidotale Retz.). Flora-Morphology, Distribution, Functional Ecology of Plants. 205 (1): 37-45.

Al-Dakheel, A.J; M.I.Hussain; A.Q.M. ARahman (2015b). Impact of irrigation water salinity on agronomical and quality attributes of Cenchrusciliaris L. accessions. Agr Water Manage. 159: 148-154.

Al-Solaimani, S. G., F. S. El-Nakhlawy; G. M.Basahui, (2009). Effect of irrigation water salinity, irrigation interval and sulphur fertilizer rates on forage yield, yield components and quality of blue panic grass (antidotale L.). J. King Abdulaziz Univ. - Meteorology, Environment and Arid Land Agriculture Sciences. 20 (2): 113-135

Arteca, R.N. (1996). Plant Growth Substances and Apllications Chapman and hall press, New York USA.PP332.

Asomaning, J.M., M. Sacandle and N.S. Olympus, (2011). Germination response of Termaliasuporba Engl. and diels seed on the 2-way grant's thermogradient plate. Res. J. Seed Sci. 4: 28-39.

Attia, S.M.; and K. M. Farag, (2017). Effect of Some Preharvest Treatments on the Incidence of Waterberry Disorder and on Fruit Quality Characteristics of "Thompson Seedless" Table Grapes AmericanEurasian J. Agric. \& Environ. Sci., 17 (5): 392-400

Basra, S.M.A., I.A. Pannu; I. Afzal, (2003). Evaluation of seedling vigour of hydro and matriprimed wheat (Triticumaestivum L.) seeds. Int. J. Agric. Biol. 5: 121123.

Cowan, Ashton, (2006). Phospholipids as Plant Growth Regulators. Plant Growth Regul. 48:97-109.

Eco crop, (2011). Ecocrop database. FAO.

Elizabeth, C; S. OumaOnguka; M. Claypool, (2016). Phosphatidylethanolamine Metabolism in Health and Disease international review of cell and molecular Biology. 321: 29-88.

FAO, (2011). Grassland Index. A searchable catalogue of grass and forage legumes. FAO.

Farag, K.M. and J.P Palta, (1993). Use of lysophosphatidyleethanolamine, anatural lipid to retard tomato leaf and fruit senescence.Pysiol.Plant. 87: 515-524.

Farag, K.M.; J.P. Palta and S.B. Ryu (2003). Methods for enhancing 
plant health, protecting plant from biotic and abiotoc stress related injuries and inhancing the recovery of plant $\mathrm{s}$ injured as result of such stresses united states Granted Patent \#6,550.099B,.

Freckmann, R. W., (2011). Antidotale. In: B. G. Baldwin et al.,(eds.), The Jepson Manual: Vascular Plants of California, Second Edition. Univ. of California Press, Berkeley.

GARE Government of the Arab Republic of Egypt, (1992). Environmental action plan, Egypt. pp. 529.

Harper, J.L. (1977). Population biology of plants. New York: Academic Press.

Heuzé V.; G. Tran; D. Sauvant, (2016). Blue panic (antidotale). Feedipedia, a programme by INRA, CIRAD, AFZ and FAO. https://www.feedipedia.org/node/4

13 Last updated on March 31, 2016, 16:26

Humphreys, L.R. and I. J. Partridge, (1995). A Guide to Better Pastures for the Tropics and Subtropics

Huxley, A. (1992). The New RHS Dictionary of Gardening. MacMillan Press 1992 ISBN 0-333-47494-5.

Ihsan, Abu-Alrub; B. Kenneth., K. Neamat, A.Ahmed Aran, M. Al Hammadi, (2018). Australian journal of crop science. Productivity and nutritional value of four forage grass cultivars compared to Rhodes grass irrigated with saline water. 12(02):203-209

Jalali, N.; N. Daneshvar; A. ShahiGharahlar; J.A. Teixeira da Silva; Farhoudi (2010). Response of Fescue (Festucarubra) to Salinity Sources and Levels at Seed Germination and Seedling Stage. Seed Sci Biotech 4(1): 33-36.

Khan, M.A., R. Ansari; H.Ali; B. Gul; B.L. Nielsen, (2009). Turgidum, a potentially sustainable cattle feed alternative to maize for saline areas. AgrEcosyst Environ. 129: 542-546.

Khan, Z. H.; I. Qadir; S. Yaqoob; R.A. Khan; M.A. Khan, (2009). Response of range grasses to salinity levels at germination and seedling stage. J. Agric. Res. (Lahore), 47 (2): 179-184.

Laxalt, A.M. and T. Munnik, (2002). Phospholipid signaling in plant defence. Curr. Opin. Plant Biol. 5: 17.

Lee, S.S; J.H. Kim (1999). Morphological change, sugar content and amylase activity of rice seeds under various priming conditions. Korean J. Crop Sci. 44, 138-142.

Liu, Y.; Q. Wang; Y. Zhang; J. Cui; G. Chen; et al., (2014). Synergistic and Antagonistic Effects of Salinity and $\mathrm{pH}$ on Germination in Switchgrass (virgatum L.). PLOS ONE 9(1): e85282

Muhammad, N., (1989). Range land management in Pakistan. International center for mountain development (ICIMOD). Khatmandu, Nepal. pp. 1-193.

Nambara, E.; A. Marion-Poll, (2005). Abscisic acid biosynthesis and catabolism. Annu Rev Plant Biol. 2005; (56):165-85.

Negrão, S.; S.M. Schmöckel; M.Teste, (2017). Evaluating physiological responses of plants to salinity stress. Ann Bot. 119 (1): 1-11.

Ogawa, M; A.Hanada; Y.Yamauchi;A. Kuwahar; Y., Kamiya; S. Yamaguchi (2003). Gibberellin biosynthesis and response during Arabidopsis seed germination. Plant Cell. 2003 Jul; 15(7):1591-604.

Olszewski, N.; T.P.Sun; F.Guble (2002). Gibberellin signaling: biosynthesis, catabolism, and response pathways. Plant Cell.; 14 Suppl():S61-80. 
Qadir, I. ; Z.H. Khan; A. Majeed; S. Yaqoob; R.A. Khan; K. Anjum, (2008). Effect of salinity on forage production of range grasses. Pakistan J. Sci., 60 (1-2): 59-63.

Quattrocchi, U., (2006). CRC World dictionary of grasses: common names, scientific names, eponyms, synonyms, and etymology. CRC Press, Taylor and Francis Group, Boca Raton, USA.

Suleman, M.K.; N.R. Bhatt; S. Jacob and R.R. Thomas, (2011). Germination studies in Ochradenusbaccatusdelile, Peganumharmala L. and Gynandrissisrinchium parl. Res. J. Seed Sci., 4: 58-63.

Tarek, H.S.; K.T. Watanabeb; Y. Oginob; K. K. Tanjic, (2000). Soil salinization in the Nile Delta and related policy issues in Egypt Ag- ricultural Water Management. 43: 239-261.

Tomar, O.S.; P.S. Minhasa; V.K. Sharmaa; R.K.Gupta, (2003). Response of nine forage grasses to saline irrigation and its schedules in a semi-arid climate of north-west India. J Arid Environ. 55: 533-544.

USDA, (2011). GRIN - Germplasm Resources Information Network.National Germplasm Resources Laboratory, Beltsville, Maryland.

Wuest, S.B., (2007). Vapour is the principal source of water imbibed by seeds in unsaturated soils. Seed Sci. Res. 17:3-9.

Wuest, S.B. and L.K. Lutcher, (2012). Soil Water Potential Requirement for Germination of Winter Wheat. Soil Science Society of America Journal, (77):279-283. 
تأثير مستويات مختلفة من الإجهاد الملحي، على إنبات بذور البلوبنيكام و إمكانية تخفيف الأضر ار بواسطة ليزوفوسفاتيديل ايثانول امين



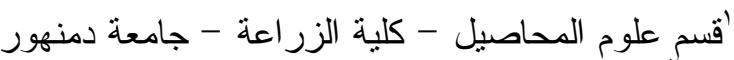 \\ "قَسم البساتين - كلية الزر اعة - جامعة دمنهور
}

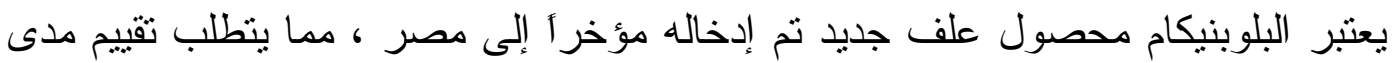

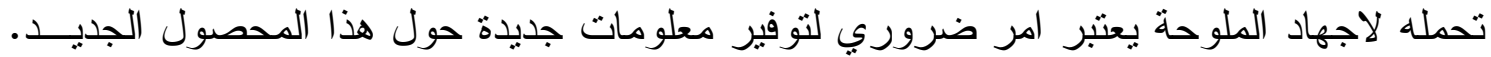

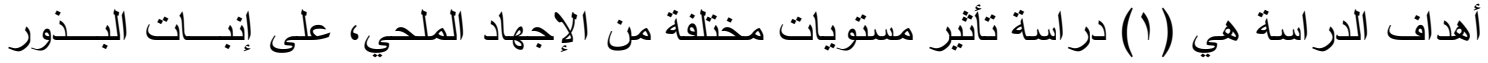

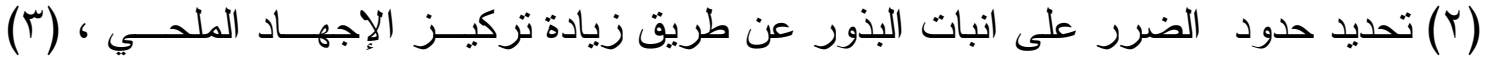

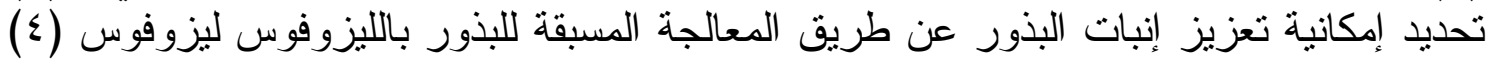

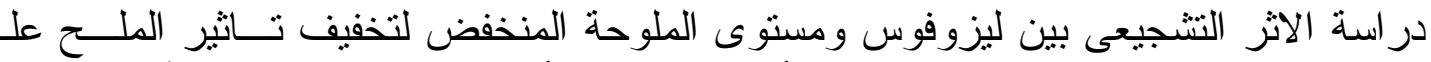

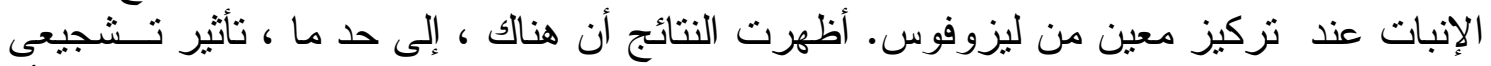

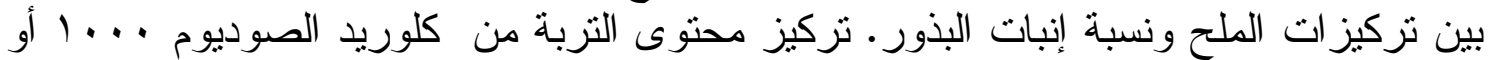

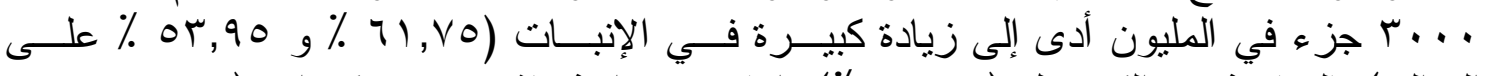

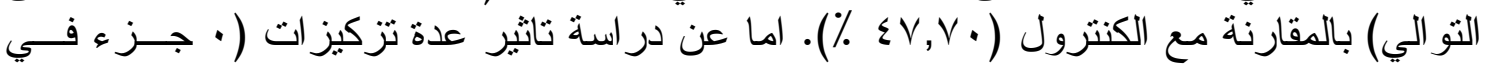



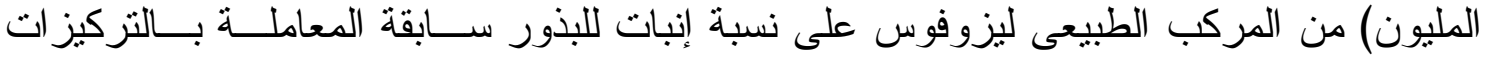



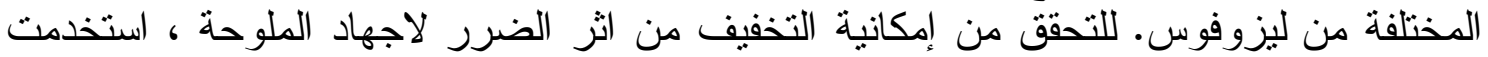

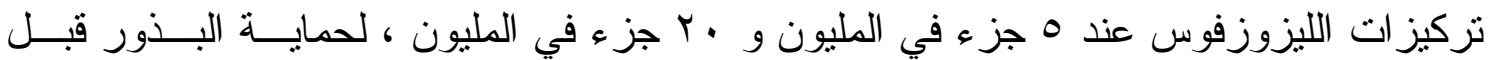

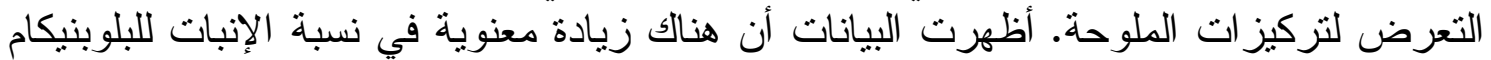

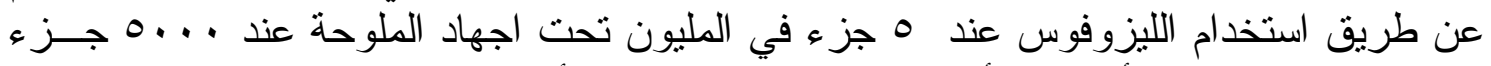

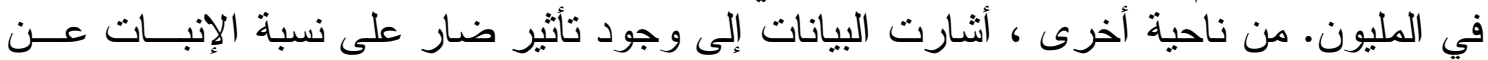

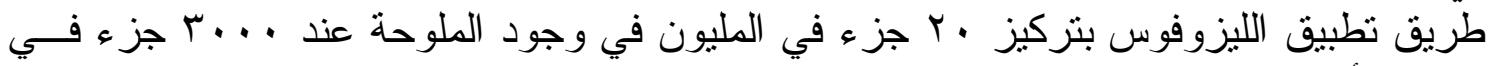

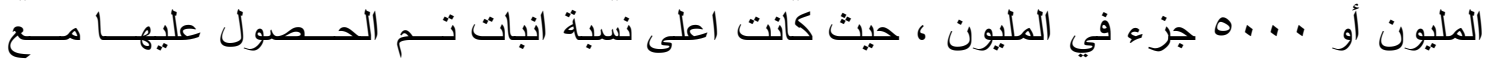




البذور على الإنبات. 